\title{
1. AN IRIDESCENT APPROACH TO PETROLEUM AND MODERNITY
}

It isn't the oil that makes us happy, but the comfortable automobile. In other words, it's a little like food: we love the roast beef but don't want to think about the slaughter house. ${ }^{1}$

A giant sculpture by Kuwaiti artist Monira Al Qadiri lies stranded on the sandy shores of the Gulf like a meteorite from an unknown future in the photograph (fig. 1.1). It has the form of a blown-up drill bit and sits within the premises of the Shindagha Heritage Village in Dubai. Made of fiberglass and then carefully coated with layers of iridescent varnish, the sculpture's smooth surface shimmers mysteriously, oscillating between orange and petrol-blue depending on the angle of the light and the spectator's position in relation to the sculpture. From the rounded body reclining on the sand, the voluminous sculpture's three narrowly connected arms stretch into the air. Each arm ends in a revolving, spiky drill bit. The tri-cone drill bit displays its flower heads to the sky like a thistle. From the ground, however, only the sharply pointed crowns are visible.

Immersed in an alienating interplay of blowing-up, decontextualization, and color change, Al Qadiri's sculpture Alien Technology alludes to the strange shapes of some of the most vital technical components of oil production. Despite the crucial importance of drill bits, which are used to bore holes (wellbores) into the Earth's crust for the extraction of petroleum, such technical objects remain unfamiliar and often hidden from view due to the fact that oil companies carefully control access to their operations. The title of the artwork also refers to the fact that, until their nationalization, the extractive industries in the Gulf were initiated and run by foreign companies and governments. The artwork's futuristic aesthetic is suggestive of the alien(ating) nature of the built environment of the Gulf cities (and elsewhere) as a consequence of petro-capitalism and the accelerated building booms it spawned. Most importantly, the artwork reflects the acknowledged challenges of petroleum's (in)visibility, its fluctuating aesthetic that facilitates but also disguises its material omnipresence. In this way, the sculpture investigates the visual and material complexity of petro-modernity through the phenomenon of iridescence.

\footnotetext{
${ }^{1}$ André Küttel, “50’300’000’000’000’000’000 Joule,” in Luca Zanier: Power Book. ed. Luca Zanier (Bern: Benteli, 2012), 7.
} 
Iridescence is the visual effect of a lustrous rainbowlike color play caused by light being reflected at different angles depending on the (changing) angle of view and of illumination. The effect is achieved by light waves reflecting from two or more semi-transparent surfaces and can be seen in soap bubbles, mother-of-pearl, and oil dispersed in water. Iridescence is not a color but a condition, a condition that is intrinsic to petroleum and pearls, two elements that have played a crucial role in the history of the Gulf. In many ways, pearling is the iridescent forerunner of petroleum extraction, as its economy thrived on cycles of boom and bust and on the luring attractiveness of the pearlescent export product. Pearling too is serendipitous. The average ratio of finding pearls was "one pearl to a thousand oysters" and yet many hoped for the one big pearl that would make the boat crew rich. ${ }^{2}$ Characteristic of the pearls claimed in the Persian Gulf was their spectrum of colors, to be "of all colors-white, black, gray, green, yellow, gold, and pink." ${ }^{3}$ And luster, their iridescent sheen, was an important criterion for establishing the Gulf pearls' quality and value, besides their shape, size, and weight. ${ }^{4}$ Obviously, iridescence is not just a color spectrum but conditional to becoming a pearl.

Iridescence is reflective of the way in which petro-modernity can enchant, seduce, and haunt us. Iridescence is a fleeting sensation that charms affectionately while it lasts and brings melancholic darkness once it vanishes. It appears as overwhelmingly beautiful, attractive, and alluring; humans go to great lengths (or rather depths) to find and extract it. Yet, iridescence is a fluctuating phenomenon that cannot be made permanent. Because it depends on the angle of the light and the position of the viewer, it is in a way as shortlived as oil. As Alien Technology demonstrates, the viewer is not simply a bystander but an intrinsic part of the experience, because the object's perfectly polished surface presents a mirror image of the approaching viewer back to them against the background of the surrounding environment. The sculpture's glossy sheen can thereby provoke selfreflection about one's own understanding and affectedness from petro-modernity's impact as both cure and poison, one's own position within the aesthetics, consumptive habits, and ecological liminalities of petro-modernity.

Scientific estimations of global oil and natural gas deposits project various deadlines for peak oil (the final climax of oil production before its rapid demise) and the subsequent grande finale of fossil fuels. ${ }^{5}$ As petroleum is not renewable, petroleum extraction will inevitably lead to an unimaginable yet total end point that leaves us with destroyed

\footnotetext{
2 Harold R. P. Dickson, The Arab of the Desert: A Glimpse into Badawin Life in Kuwait and Saudi Arabia, 4th ed. (London: George Allen \& Unwin, [1949] 1967), 491. A decade later, Bowen states that "less than onethird of the oysters yield pearls and these are mostly 'seed pearls', those very small irregularly-shaped pearls which might well be called 'pearl dust.” Richard L. Bowen, "The Pearl Fisheries of the Persian Gulf," Middle East Journal 5, no. 2 (1951): 175.

3 Bowen, “The Pearl Fisheries of the Persian Gulf," 162.

${ }^{4}$ See ibid., 161-62.

${ }^{5}$ Scholars have emphasized that the inaccurate predictions and statistics of peak oil, of oil production rates, and of worldwide oil reserves is both startling and characteristic of the oil industry. See Hannah Appel,
} 
landscapes and unsatisfiable habits of consumption and will most likely herald the end of the world as we know it today. Petroleum has been the single most important material of the Anthropocene. It is currently a prime source of energy used by humans and the most versatile raw material: in its various permutations it is found in almost every consumer good, in every trash heap, and, increasingly, as implants and microplastics, in our bodies, too. $^{6}$ Therefore, as many scholars argue, it is almost impossible to imagine what a world "after oil" could possibly look like.

For the Gulf states, this uncertain future perspective also stimulates haunting scenarios of the region without oil revenues. Because current standards of living are not sustainable without oil as energy, income, and raw material, extreme future imaginaries sometimes depict the currently sky-rocketing and sky-rising Gulf capitals as re-sinking, disappearing into the sand, following petroleum's path of extraction in reverse. ${ }^{7}$ In addition, as energy humanist Andreas Malm argues, the Persian Gulf will at some point have some of the most unbearable climatic conditions on the planet. ${ }^{8}$ A tragic irony lies in the prediction that "fossil fuels from the Gulf are poured on fires across the globe and then return, via the concentration of $\mathrm{CO}_{2}$ in the atmosphere, to haunt the area with a particularly stark form of the general predicament [global warming]." In light of this dystopian boomerang effect, at a time when oil prices are dropping and people are rethinking fossil fuel industries and energy consumption due to increasingly rapid climate change, it is not surprising that academics and artists from the Gulf and elsewhere are reassessing the region's recent past, a past that has been both swimming and drowning in petroleum.

The almost unimaginable variety of petroleum-derived products and the almost total petro-infiltration of not just the Gulf but of our world in general make it very challenging to re-extract - as a cultural analysis - petroleum from our common and often comfortable ways of living. Petroleum gives way to a complex regime of (in)visibility because it is somehow everywhere and in everything, but its synthetization redirects our experience and knowledge of petroleum via other materials, forms of energy, infrastructure, and images. It becomes especially challenging to analyze petroleum's visuality and aesthetics,

Arthur Mason, and Michael Watts, “Oil Talk: Introduction," in Subterranean Estates: Life Worlds of Oil and Gas, ed. Hannah Appel, Arthur Mason, and Michael Watts (Ithaca: Cornell University Press, 2015), 5-9.

6 Damian Carrington, "Microplastics Revealed in the Placentas of Unborn Babies," The Guardian, December 22, 2020, accessed January 27, 2021, https://www.theguardian.com/environment/2020/dec/22/microplastics-revealed-in-placentas-unborn-babies.

7 This also echoes the fate of oil towns such as Pithole, Pennsylvania, an oil boomtown in the mid-1860s that was abandoned as early as 1868 . Today it is a ghost town.

${ }^{8}$ Andreas Malm, "This Is the Hell That I Have Heard of': Some Dialectical Images in Fossil Fuel Fiction," Forum for Modern Language Studies 53, no. 2 (2017): 123. Malm bases his prediction on two climate research results: Jeremy S. Pal and Elfatih A. B. Eltahir, "Future Temperature in Southwest Asia Projected to Exceed a Threshold for Human Adaptability," Nature Climate Change 6, no. 2 (2016) and J. Lelieveld et al., "Strongly Increasing Heat Extremes in the Middle East and North Africa (MENA) in the 21st Century," Climatic Change 137 , no. $1 / 2(2016)$.

9 Ibid., 123. 
its visual culture and the ways in which this has shaped how we experience the world through images and media that are fossil energy-based or materially constituted from petroleum. When we see plastic (or the visual representation of a plastic object), for example, we do not see petroleum as crude oil-we see plastic. Yet plastic has a complex history of its own. It is also a composite, extremely versatile material that has been pivotal for the development of visual technologies such as film and photography; it has even given way to a new plastic-like aesthetic of the world. But despite its omnipresence, the fact that plastic originates from petroleum is acknowledged and experienced only peripherally, if at all.

Over the recent years, studies on the social and cultural implications of oil have established a certain range of representative phenomena of oil through which to read or analytically assess how the substance has infiltrated ways of living and ways of constructing and experiencing the world. Given that certain materials, objects, and lifestyles cannot exist and work the way they do without petroleum, they can be considered emblematic of petro-modernity. Such phenomena have been, for example: infrastructure supporting the production of petroleum, such as oil derricks, offshore platforms, pipelines, and oil tankers; means of transportation that run on fuel oils, such as automobiles, trains, airplanes, and ships; and all forms of plastics that synthesize our world, including Bakelite, polyethylene (bottles, plastic film), nylon (toothbrushes), polyester (fabrics), and silicone (sealant, also in industrial paints). However, the proliferation of petroleum imagery and its petroleum-based visual technologies has not yet been comprehensively examined as emblematic of petro-modernity.

This book investigates the visual culture of petro-modernity, that is, the images that petroleum has brought about and the ways in which petroleum and petroleum-derived products shape how we experience the world aesthetically and visually. In this context, iridescence is conceptualized as the aesthetic staging of the broader normalization of the Anthropocene, as petro-modernity, in which Kuwait provides for a historic microcosm of this Anthropocenic macrocosm. The investigation is carried out using the case of the mid-twentieth-century urban transformation of Kuwait, a city-state that quickly became a prime oil producer. Although the oil industry in Kuwait was run outside of Kuwait City by the Anglo-American Kuwait Oil Company, the rapidly expanding city became the representational stage on which petro-modernity unfolded in multiple iridescent ways. The urban visual culture that developed alongside negotiated this oilfueled transformation that coincided with Kuwait's nation-building. For this book, Alien Technology serves as a figure of thought that reenacts what can be called the iridescent effect-petroleum's ability to not only have a powerful material presence in other materials, in other textures, and objects, but, most importantly, to have a powerful aesthetic, material, and visual presence or resonance in images, in media, in the built environment, and in space in general. Finding and dissecting the iridescent effect in the visual media that emerged in connection with the mid-twentieth-century urban transformation of Kuwait City provides an analytical lens with which to detect those aesthetics and tactics of visual 
seduction that have created the affective relationship with petroleum, but more broadly with global petro-modernity with which we continue to deal with today.

The focus on the visual is based on the understanding that the imagery of Kuwait City's "modernization" from the mid-1940s onward not only documented and displayed but visually constructed the ways in which the petro-fueled urban transformation was perceived and the ways in which petro-modernity was negotiated. The extended 1950sthe period between 1946 and 1961, from the first shipment of oil to the independence of the Kuwaiti nation-state from Great Britain-were not just a key period of urban transformation and oil production, but a period infused with ideas of nation-building and modernization. In this period, Kuwait experienced the development of a welfare and bureaucratic state apparatus and the transmutation into a fullfledged nation-state, most of it under the reign of Shaykh Abdullah al-Salem Al Sabah. ${ }^{10}$ Kuwait's nation-building was deeply entangled in oil revenues and the adoption of an oil-based material way of being in the world. Inherent to the logic of both modernization (theory) and nation-building is the question of how to develop from the present into the future. In these early days of the Kuwaiti nation-state, but in fact until the present day, the answer to this question has always involved petroleum. With this logic came the petroleum promise, which is the affective visual and/or textual framing of petroleum as a harbinger of future change and prosperity in speculative anticipation of its production or of its continuation. ${ }^{11}$ In a way, there is always a future-making involved and this affective potentiality has attracted visualization, or rather visual representation. In the mid-twentieth century, aerial photographs, maps, architectural plans, political symbols, photography, architecture, stamps, travel guides, and even visual arts were not mere reflections or by-products of the processes of petromodernity, nation-building, and modernization. They were, rather, active components that enabled and shaped these processes and imbued them with meaning.

Recontextualizing the images of mid-twentieth-century Kuwait City in the emerging urban visual culture of the time is an attempt to "re-carbonize" modernity in order to disclose the otherwise blurry or even invisible complicity of petroleum in it. To re-walk all the little alleyways and big highways that petroleum has tinted is a method of giving oil visibility through which it can be analyzed as a crucial factor or medium in the modern history of the Persian Gulf and in capitalist globalization at large. Indeed, as it is often difficult to see the forest for the trees, the somewhat pointed emphasis on oil within the present study is essential for leaving the current state of petroleum-blindness behind.

\footnotetext{
${ }^{10}$ Shaykh 'Abdullāh al-Salim al-Mubārak Āl Șabāḥ (January 1, 1895-November 24, 1965) ruled Kuwait from January 29, 1950 to his sudden death in November 1965. His predecessor was Shaykh Ahmad Jābir Āl Șabāh (born 1885), who ruled from March 29, 1921, until his death on January 29, 1950.

${ }^{11}$ Slightly differently, Mona Damluji defines "petroleum's promise" as "the promise of nation building and modernization of oil-producing states" that was linked to "the neo-colonial practice of oil extraction." Mona Damluji, "Petroleum's Promise: The Neo-Colonial Imaginary of Oil Cities in the Modern Arabian Gulf" (PhD diss., University of California, Berkeley, 2013), accessed January 27, 2021, https://escholarship.org/uc/ item/7qk5c7kj, 2.
} 
Petroleum's ubiquity is not exclusive to Kuwait's specific geopolitical and historical conditions, but the extreme concentration of oil in Kuwait's history makes the city-state a thought-provoking prism through which to detail and exemplify larger discourses, developments, conditions, and consequences of the global petro-modernity we all live in today.

The case study of Kuwait is emblematic of the global collective disillusionment with modernity (which has been a carbon modernity, involving first coal, then oil), with petroleum as the source of planetary destruction, and the ideologies (progress, nationalism, modernization, etc.) around it. Petroleum was dealt as the promise of modernity to fuel both center and periphery, but living with and in petroleum has proven to be a temporary cure and a lasting curse that are not accidentally but programmatically worked into the construction of our global modern history and the construction of Kuwait's history. Therefore, I see the regional response to the legacies of the "petroleum promise" in contemporary visual culture as a sounding board to which extent these ideologies, narratives, and imaginaries have persisted and convinced, or disenchanted and fallen apart. A younger generation is answering back through contemporary artworks which become acceptable forms of visual expression that respond in the (semi-)public arena. Circulating around notions of memory, nostalgia, collective identity, and futurism, these artworks on the one hand prove the lasting effect of the iridescent effect, and on the other hand, they demonstrate the growing resistance to such narratives. The apparent political, economic, and social stability that petroleum promised to establish has transformed into a planetary realization of how instable petro-modernity has made the past, present, and future, and its imagery.

The book Iridescent Kuwait seeks to do two things. At the base, it maps, describes, analyzes, and compares urban images of Kuwait using a media-historical and iconographic approach in order to understand which cultural artefacts, tropes, motifs, images, and aesthetic practices have come to (not) represent the negotiation of petro-modernity in Kuwait. Here, the focus lies on representations of architecture and the Gulf city in urban visual culture rather than on the actual built environment. At a second level, this book traces the ways in which petroleum has constituted modernity as iridescent. To do so, I investigate (1) how petro-urbanism dictated the transformation of urban space, (2) how the rise of new modes and technologies of viewing and image-making was enabled by petroleum in one way or another, and (3) how the aesthetic complexity and seductive attraction of petro-modernity is tangled up in a myriad of promotional strategies that hide petroleum's toxicity from view. Ultimately, thinking through petro-modernity allows us to view the development of our modern world not as a piecemeal combination of "avantgarde" and "belated" modernities, but as one modernity that is drenched in petroleum and from which no one can escape.

This introductory chapter (Chapter One) explores the methodological and theoretical prerequisites surrounding the core themes of urban visual culture, petro-modernity, modernization (theory), and urban transformation. Chapter Two provides a historical 
overview of Kuwait's socioeconomic and cultural formation as well as its spatial configuration until the mid-twentieth century. It offers a particular focus on the pre-oil urban morphology and architecture that would later become the site of major oil-fueled overhauls and considers the early stages of visual arts, their production, and display in Kuwait. Together, the theoretical opening and the historical background provide the basis for the subsequent three main chapters.

Chapter Three deals with how Kuwait (City) was visualized and envisioned in aerial photography, Kuwait City's first master plan, and cartography. The view from above triggered lasting representational ambiguities of seeing and understanding the pre-oil town of Kuwait as well as the "oil city" Kuwait. This top-down view resulted in a top-down approach in urban planning that Arab and Kuwaiti architects and urban planners critically reexamined in the following decades. Chapter Four focuses on the Kuwait Oil Company's seminal publication The Story of Kuwait and the company's use of professional (color) photography to present Kuwait City as a success story of petro-fueled modernization with lasting effect. By comparing these images with photographs by Kuwaiti photographer Tareq Sayid Rajab and urban images of Kuwait in the magazine $a l-A r a b \bar{i}$, the prerequisite destruction of the existing town of Kuwait that occurred side by side with its colorful modernization provides for a more complex picture of the city's transformation and highlights varying, at times contrasting agendas by different actors. Chapter Five addresses the ways in which the Kuwaiti government used the first set of Kuwaiti postage stamps to promote the country as a self-confident and modernizing petro-state and how the accompanying process initiated the country's independence in 1961. Oil stamps, or petro-philately, became an important medium in the Arab world to show a nation-state's participation in petro-modernity.

As a short parenthesis, Chapter Six recalls the falling apart of Kuwait's petroleum promise by shedding light on the visuality and mediality of Kuwait's biggest petroleum calamity surrounding the Iraqi invasion, Operation Desert Storm, and the oil spills in 1990-91. This rupture in Kuwait's oil history reveals the full spectrum of petro-modernity, shifting from cure to curse and coming full circle in iridescence. Chapter Seven, the final chapter, reintroduces the sculpture Alien Technology along with a selection of other works of contemporary art from the Gulf that deal with petro-modernity's past and present in the region, and the corresponding theoretical discourse. By combining these contemporary perspectives with the findings of the previous chapters I discuss the ways in which the twentieth-century urban visual culture of petro-modernity is questioned today and how to come to terms with its ever-seductive aesthetics as well as the role the Gulf plays in sketching future global scenarios of with and without oil in the visual arts. 


\subsection{Urban Visual Culture}

Today, historical images of the Gulf region feverishly circulate within the region itself. Apart from self-published photobooks and memoirs, websites, blogs, and social media accounts also bring to light a multitude of historical photos, films, and video snippets. Photographs of a wide range of paraphernalia like old posters, stamps, and even tableware of Kuwait Airways are being unearthed in a collective, transgenerational effort. ${ }^{12}$ Clearly, a large interest in seeing, sharing, and thereby revisiting the Gulf's, a country's, and ultimately one's own past beyond established national forms of memory, history, and heritage exists. Given current technological means of publishing and sharing visual material, provenience is often impossible to establish. Yet these images keep moving, keep attracting attention, and keep posing questions to scholars of urban visual culture.

When I first visited the Gulf in 2016, I was intrigued by the plethora of historical visual material; this included historical photographs, city maps, stamps, paper money, company brochures, and government-issued coffee-table books. I wanted to move beyond a mere fascination with these objects. To this end, I developed a material-driven approach, working with material readily available instead of rejecting it in favor of other sources that might be considered more worthy of study by some. In art history it is often considered legitimate to engage with particular material when an artifact is in an archive, museum, or renown private collection (showing that it is considered worth preserving), when it has authorship (meaning that its originality, influences, and mastery can be studied), or when it speaks to established (fine) art categories and traditions (that make it compatible with classifications and canon). Much of the imagery analyzed in this book holds no artistic authorship, was not intended to be art, and has not necessarily been viewed as such. It has often become integrated into everyday popular culture and has thereby easily transcended elite circles-even if members of these circles were usually involved in its creation and dissemination - and for which it is often difficult to find historical evidence detailing its reception. Rather than the cityscape in watercolor, most historical images discussed in this study have been produced, circulated, and consumed within the logic of mass culture and mechanical or industrial reproduction, where authenticity or originality are not the most important criteria. How can we engage with this material in art history if it is not art as we know it?

From the 1990s, debates within visual culture studies, which often spilled into art history departments, campaigned to broaden the object of study to encompass all possible

\footnotetext{
12 Among others there is Mādì al-Kuwayt (mostly in Arabic with some sub-pages translated into English), although a part of the images has been recently taken down; accessed January 27, 2021, https://www.kuwaitpast.com/arabic.html. On this phenomenon in the Arab world, see Lucie Ryzova, "Nostalgia for the Modern: Archive Fever in Egypt in the Age of Post-Photography," in Photo Archives and the Idea of Nation, ed. Costanza Caraffa and Tiziana Serena (Berlin: De Gruyter, 2015).
} 
expressions of the visual, irrespective of intention and reception. ${ }^{13}$ Accordingly, in this study, visual culture is understood as all expressions of imagery with no restrictions as to their form, typology, medium, or the type of material. Despite continuing discussions about the relationship between visual studies and art history, visual culture does not work in opposition to art but rather as its enlargement, as its umbrella term. Both art itself and the academic discipline history of art are part of (the study of) visual culture. As Christine Gruber and Sune Haugbolle suggest in Visual Culture in the Modern Middle East, visual culture studies and art history enhance each other as two fields of expertise and knowledge production. ${ }^{14}$ Visual studies are strong in the theoretical analysis of, for example, representations of race, gender, and power. Yet, as Gruber and Haugbolle emphasize, many studies do not pay close attention to the formal composition of the image, (political) iconography, the historical modes of image production, reception processes, and especially notions of "aesthetics." 15 Art-historical methods are notably strong in the analytical description of images as well as in their comparative and historical image-to-image analysis. Consequently, the imagery discussed in this book is approached using the methodological and theoretical apparatus of art history, despite it being material that many art historians might ignore. In addition, close attention is paid to inherent power relations, to questions of (political) representation, and ecology.

Of central importance to the question of how the imagery that is discussed in the following chapters acquires meaning is the relationship between the built environmentas physical, multisensorial, and also strong visual experience-and the image. This relationship is conceptualized as visual representation. Images of Kuwait City (as visual representations) can be understood to lastingly influence the city's image (as appearance and reputation). Analyzing such images serves not only to illustrate urban history; rather, visual representations form an object of study in their own right that can help us better understand the ways in which meaning is acquired. The pervasiveness of images lies in their apparent structural and visual consistency, yet images are highly ambivalent and open to changes in meaning and readings. Images of Kuwait City are understood to hold power to affect the material realities of urban space in return; visual representations therefore construct that which they represent, ultimately constituting our understanding of the world. ${ }^{16}$

\footnotetext{
${ }^{13}$ For a pertinent summary and historical examples of this discussion see William I. Homer, "Visual Culture: A New Paradigm," American Art 12, no. 1 (1998); Johanna Drucker, "Who's Afraid of Visual Culture?” Art Journal 58, no. 4 (1999).

${ }^{14}$ Christiane J. Gruber and Sune Haugbolle, "Introduction: Visual Culture in the Modern Middle East," in Visual Culture in the Modern Middle East: Rhetoric of the Image, ed. Christiane J. Gruber and Sune Haugbolle (Bloomington: Indiana University Press, 2013), xvii-xix.

15 Ibid., xvii.

${ }^{16}$ See Susan Sontag, “The Image-World," in On Photography, ed. Susan Sontag, repr. ed. (New York: Rosetta Books, [1977] 2005).
} 
This study is dedicated to the visual culture of the Gulf city, the mutual constitutive relationship between images and the city, and the ways in which they reenforce, inform, shape, and negotiate each other, for which I conceptualize as "urban visual culture." In a seemingly similar approach provided with the special issue "Urban Images and Imaginaries: Cities of the Arabian Peninsula through their Representations" in the journal Arabian Humanities (2019), Laure Assaf and Clémence Montagne consider images "both as object and method, seeking to explore what urban images do to contemporary Gulf cities," which implies focusing on "who produces these images" with its political and social implications as well as "the way urban images shape the city itself." ${ }^{17}$ Part of the "urban visual culture" as I understand it, is of course the city's "architectural culture," as Sibel Bozdoğan has described it in Modernism and Nation Building: Turkish Architectural Culture in the Early Republic: "The idea behind the study of architectural culture is not to explain the work through what was said and written about it but to see the ways in which what was said, written, and built collectively confirm, interpret, contest, or negotiate the political and ideological agendas of the time." ${ }^{18}$ Still, this book is predominantly concerned with the visuality, the aesthetics, the modes of representation, and the discursive elements that arise in relation to Kuwait's modern architectural culture, which has been surveyed in the two volumes of Modern Architecture Kuwait $(2016 ; 2018)$ by its authors and editors Roberto Fabbri, Sara Saragoça, and Ricardo Camacho, and in relation to its urban history as examined by Farah Al-Nakib in Kuwait Transformed: A History of Oil and Urban Life (2016). ${ }^{19}$

Conceptualized as part of Kuwait's urban visual culture, the images examined here allow us to analyze the ways in which the urban experience of petro-modernity was negotiated. To this end, methodologically, the present analysis focuses on the way in which the visual material speaks to other images and viewers in terms of content, formal structure, iconography, time of origin, political implications, media, context, and the historicity of themes and topics. Subsequently, their meaning is investigated in relation to other larger histories, debates, and themes relevant for mid-twentieth century Kuwait and the Gulf.

\footnotetext{
${ }^{17}$ Laure Assaf and Clémence Montagne, "Urban Images and Imaginaries: Gulf Cities through their Representations," Arabian Humanities, no. 11 (2019): 2, https://doi.org/10.4000/cy.4137.

${ }_{18}$ Sibel Bozdoğan, Modernism and Nation Building: Turkish Architectural Culture in the Early Republic (Seattle: University of Washington Press, 2001), 12 (italics in the original).

19 Roberto Fabbri, Sara Saragoça, and Ricardo Camacho, Modern Architecture Kuwait: 1949-1989 (Zurich: Niggli, 2016); Roberto Fabbri, Sara Saragoça, and Ricardo Camacho, eds., Essays, Arguments \& Interviews on Modern Architecture Kuwait (Zurich: Niggli, 2018); Farah Al-Nakib, Kuwait Transformed: A History of Oil and Urban Life (Stanford: Stanford University Press, 2016).
} 
Representation and modernity share a complex historical relationship. Timothy Mitchell, for example, argues that modernity can be defined by "the way in which the modern is staged as representation." ${ }^{20} \mathrm{He}$ details:

Representation does not refer here simply to the making of images or meanings. It refers to forms
of social practice that set up in the social architecture and lived experience of the world what seems
an absolute distinction between image (or meaning, or structure) and reality, and thus a distinctive
imagination of the real. ${ }^{21}$

Mitchell subsequently implies that one way to think of modernity is as an experience negotiated through representations, which is a way of communicating between "world-aspicture" and "reality." 22 The case of Kuwait suggests that, as early as the 1950s, modernity worked effectively as a system of visual regimes, whereby the visual meaning or success of meaning-making was somewhat independent of the performative functionality that modernity is usually associated with. Large infrastructure projects, for instance, gained importance as active visual signposts quite independently of their technological function. Therefore, in Kuwait and in many decolonizing and nation-building contexts, modern architecture and modern urban space were more effective, virulent, and powerful as visual representations of modernity in the form of images than as physical harbingers of change. ${ }^{23}$

Images also have the power to profoundly shape our understanding of cities and their urban history from a transnational perspective. Pictures are significant agents of knowledge, of imaginaries, and of cultural exchange. They can become traveling vehicles of meaning in their ability to transgress natural, political, linguistic, cultural, and temporal borders. So, they can effectively overcome the otherwise geographical, spatial, and physical fixation of urban space and architecture. Given this mobility, historical visual material is best examined "as belonging in a continuing process of meaning, production, exchange, and usage," a focus that photography historian Elizabeth Edwards calls "the social biography" of images. ${ }^{24}$ This involves resituating images in their complex sociocultural, geopolitical, and historical context as best as possible by working extensively with archival material as well as concepts, knowledge, and theories produced in other disciplines such as anthropology, Gulf and Middle Eastern studies, political science, sociology, and energy humanities.

The proliferation of visual media during the era of petro-modernity has often served to regulate, and thereby soften, its potentially controversial aspects-what I understand

${ }^{20}$ Timothy Mitchell, “The Stage of Modernity," in Questions of Modernity, ed. Timothy Mitchell, Contradictions of Modernity (Minneapolis: University of Minnesota Press, 2000), 16.

${ }^{21}$ Ibid., 17.

22 Ibid., 18.

${ }^{23}$ For similar arguments in favor of the "visible politics" of architecture see Bozdoğan, Modernism and Nation Building, 9.

${ }^{24}$ Elizabeth Edwards, “Material Beings: Objecthood and Ethnographic Photographs," Visual Studies 17, no. 1 (2002): 68 . 
as the iridescent effect. Rendered visible through promotional materials, radiant color palettes, or impressive advances in technological modes of seeing, its environmental and social rapaciousness has been effectively hidden from view. Energy humanists Sheena Wilson and Andrew Pendakis emphasize that "in the age of oil it is the image, at this time more than in any other era, that proliferates as a medium of communication." 25 However, the visual symbolic practices that carefully curate petroleum's (in)visibility not only communicate, but also construct the experience of petro-modernity. While most of the discussion of the relevant literature is woven into each chapter when and where it is needed, the theoretical framework around petro-modernity that supports this study as a whole deserves its own discussion.

\subsection{Petro-Modernity}

Petroleum, or simply oil (the two terms are used interchangeably throughout), is a composite substance consisting of many different hydrocarbons that can be liquid, gaseous, or solid. The terms denote both unprocessed and naturally found crude oil as well as industrially refined petroleum products. As raw material it is formed from dead organisms under extreme heat and pressure, an "ur-commodity," as cultural theorist Imre Szeman suggests. ${ }^{26}$ Petroleum has many useful characteristics: it is flammable (producing light, heat, fire, energy), viscous (sealing and lubricating surfaces and materials), heterogeneous (separable into different products with specific characteristics), and odorous (many consider it malodorous). Some cultures have also ascribed healing abilities to it, and advocate rubbing one's skin with crude oil or consuming small amounts of treated oil. In natural deposits, petroleum often occurs as a black, very sticky, and highly viscous liquid or semi-solid heterogeneous substance referred to as asphalt, bitumen, or tar. Petroleum's material complexity has been known to humankind for more than four thousand years, but it only gained unprecedented momentum once it began fueling modernity, once it became iridescent.

In order to make use of (and create value from) petroleum, it needs to be extracted, transported, catalyzed, refined, and synthesized. ${ }^{27}$ Since the mid-nineteenth century, various refining processes have been invented, most involving some form of fractional distillation that separates the heterogeneous hydrocarbon-complex into homogenous

\footnotetext{
${ }^{25}$ Andrew Pendakis and Sheena Wilson, "Sight, Site, Cite: Oil in the Field of Vision," Imaginations: Journal of Cross-Cultural Image Studies 3, no. 2 (2012): 4.

${ }^{26}$ Imre Szeman, "Introduction to Focus: Petrofictions," American Book Review 33, no. 3 (2012): 3 (italics in the original).

${ }^{27}$ For a sharp analysis of the refinery as "a form of heart chamber that pumps fossil raw materials into the present" by means of the pipeline and the cultural technology of catalysis, see Benjamin Steininger, "Refinery and Catalysis," in Textures of the Anthropocene: Grain, Vapor, Ray, ed. Katrin Klingan et al. (Cambridge, MA/ Berlin: MIT Press; Revolver, 2015).
} 
products and that thereby ultimately changes petroleum's consistency, smell, shape, color, energy level, and usability. Primary petroleum-based products are the different types of energy-rich fuel oils-petrol, gasoline, propane, naphtha, kerosene, diesel, and liquefied petroleum gas-that comprise the world's most important energy sources. Other components produced during the refining process are used as a raw material or as reagents for a diverse range of chemically synthesized products.

Oil has given birth to plastics, cosmetics, pesticides, and all kinds of textiles, from maritime ropes to wedding dresses. It is a fertilizer component used for our industrialized mass agriculture. As asphalt it aids mobility around the globe. It lubricates tools and machinery. Prior to the digital age, it led to the celluloid and inks necessary to produce film, photography, and printed materials, and through this enabled most of the material and visual culture of the twentieth century. In the mid-twentieth century petro-modernity began manifesting itself rapidly everywhere around the world. Following the end of World War II, oil explorations were started or resumed across the globe and myriads of new uses for petroleum and its derivatives were promoted as part of local everyday culture. Petroleum-derived commodities were now developed into personalized forms of mobility and lifestyle that eventually affected all social strata. Kuwait City's urban development and the city-state's nation-building thus coincided with the global expansion of petromodernity during the extended 1950s.

Viewed from this perspective, modernity since the 1850 s-but particularly since the mid-twentieth century-to this day has been a petro-modernity drenched in and dependent on the same resurrected organic matter. Consequently, modernity, postmodernity, and "multiple modernities" depend on the same material condition. This invites a reconsideration of epochal delineations and their attributed characteristics. ${ }^{28}$ Prominent scholars such as Zygmunt Bauman and Bruno Latour have already questioned and opposed the distinction between modernity and postmodernity. ${ }^{29}$ Looking through the lens of petroleum, however, one can detect a fossil continuum spanning from the classical industrial revolution (fired by coal, another fossil carbon) to the digital age. ${ }^{30}$ Even the digital age continues to be highly dependent on oil in order to satisfy the large energy demand of the smart lifestyle we have come to take for granted. ${ }^{31}$ This also resonates with Nicolas Mirzoeff's reading of Dipesh Chakrabarty's essay “The Climate of

\footnotetext{
${ }^{28}$ As our dependency on petroleum has not declined in importance and as we cannot yet imagine a life "after oil" (meaning a life without any or at least one with substantially less petroleum), general differentiations between modernity and postmodernity cannot be upheld from the perspective of oil, as they de facto run on the same material conditions.

${ }_{29}$ Zygmunt Bauman, Liquid Modernity, repr. ed. (Cambridge: Polity, [2000] 2006); Bruno Latour, We Have Never Been Modern (Cambridge, MA: Harvard University Press, 1993).

${ }^{30}$ Frederick Buell, “A Short History of Oil Cultures: Or, the Marriage of Catastrophe and Exuberance," Journal of American Sudies 46, no. (2012).

31 The digital economy, which is often considered to be fossil-free, was already consuming ten percent of the world's total energy (mostly produced from fossil fuels) by 2015. This represents the same amount that was
} 
History". The visual culture theorist concludes pointedly: "In the Anthropocene [the era brought forth by humans, especially by burning fossil fuels], all past human history in the industrial era is the contemporary. No location is outside the Anthropocene, although some are affected far more than others." ${ }^{32}$ Focusing on petroleum invites us to rethink our global history and its material conditions as fundamentally common and interconnected. Center and periphery as well as avant-garde and "rear guard" have shared similar material conditions of being in this modern world, even if to very different degrees.

Everything we do, feel, and see is touched by oil, infused with petroleum; yet, analytically, we have long blanked out the crude conditions of producing, living, and experiencing our modern world. The question looms large why the humanities and social sciences have ignored energy and petroleum for so long. For one, there is the almost unimaginable size of the industry as well as the incalculability and often inaccuracy of numbers and timelines (peak oil, production outputs, oil prices, etc.), which scholars in the field attest to causing "intellectual vertigo." ${ }^{33}$ Most importantly, to be hidden in plain sight is an acknowledged characteristic of petroleum (and other forms of energy).

Questions of aesthetics, visual representation, and (in)visibility in particular have posed challenges for researchers across all fields. ${ }^{34}$ Andreas Malm and others explain this as a "crisis of the imagination," caused among other things by the material fugitiveness and infrastructural disguise of petroleum. ${ }^{35}$ Artist Ursula Biemann, who was one of the first to systematically approach the politics of petroleum through artistic research, sees "this level of abstraction in the representation of oil as yet another way to keeping it firmly in the hands of market dynamics." ${ }^{36}$ Literature scholars Andrew Pendakis and Sheena Wilson also point to petro-capitalism and argue that "the problem of visualization ... is not specific to oil, but one politically structural to a system that is at once spectacularly consumerist and fully globalized on the level of production." ${ }^{37}$ In order to begin to imagine alternatives to oil, we first have to dissect how petroleum has come to shape how

used to light the entire planet in 1985. See Shumon Basar, Douglas Coupland, and Hans Ulrich Obrist, The Age of Earthquakes: A Guide to the Extreme Present (New York: Blue Rider, 2015), n.p.

${ }_{32}$ Mirzoeff explains the Anthropocene as "the name given by scientists to the new era in geology caused by human intervention, primarily the burning of fossil fuels." Nicholas Mirzoeff, "Visualizing the Anthropocene," Public Culture 26, no. 2 (2014): 213, 215; Dipesh Chakrabarty, “The Climate of History: Four Theses," Critical Inquiry 35, no. 2 (2009).

33 Appel, Mason, and Watts, "Oil Talk," 5-9.

34 Scholars have emphasized "the surprising limits of aesthetics and representation in relation to energy". Sheena Wilson, Imre Szeman, and Adam Carlson, "On Petrocultures: Or, Why We Need to Understand Oil to Understand Everything Else," in Wilson, Carlson, and Szeman, Petrocultures, 5; see also Ross Barrett and Daniel Worden, “Oil Culture: Guest Editors' Introduction,” Journal of American Studies 46, no. 2 (2012): 269; Appel, Mason, and Watts, "Oil Talk," 4-5.

${ }^{35}$ Malm, “This Is the Hell That I Have Heard of," 126.

${ }^{36}$ Ursula Biemann and Andrew Pendakis, “This Is Not a Pipeline: Thoughts on the Politico-Aesthetics of Oil," Imaginations: Journal of Cross-Cultural Image Studies 3, no. 2 (2012): 8.

${ }^{37}$ Pendakis and Wilson, "Sight, Site, Cite," 4. 
we see our modern world. Consequently, scholars have started revisiting works considered "canonic" as well as introducing formerly marginalized material within their respective fields to understand where, why, and how petroleum has slipped the critical viewer's or reader's eye.

For a long time, chemists and engineers, as well as economists and political scientists, have dominated the study of petroleum. However, in asking what petroleum does in social and cultural contexts, recent studies have argued that oil (and energy) are pivotal in shaping habits, ways of living, modes of transportation, and even our epistemologies. ${ }^{38}$ Lately, a large part of the knowledge production on petroleum has developed from a social and cultural perspective and especially in the field of energy humanities, an interdisciplinary field across the arts, humanities, and social sciences.

Energy humanities works to "position oil and energy as the fulcrum around which many of today's most pressing social, economic, and political issues must be analyzed and understood." ${ }^{39}$ Energy humanists have argued that "while it would be reductive to see in the expanded use of energy an explanation for every aspect of modernity, it is equally problematic not to include energy in our narratives of historical change and development, including social and cultural shifts and transitions." ${ }^{40}$ Here, reflecting on petroleum means partaking in a larger analysis of the social and cultural implications of energy transitions, meaning the values, practices, affects, hopes, beliefs, aesthetics, modes of vision, and representation that petroleum enables. In light of future scenarios "after oil," we need to recognize and reconsider the paramount role fossil energy has played in the "historical formation" of modernity. ${ }^{41}$ Especially because there is a high chance that petroleum will not be gone as quickly or completely as usually insinuated with terms such as "post-oil" or "after oil." Michael T. Klare, a professor of peace and world security studies at Hampshire College, convincingly argues that the upcoming "Third Carbon Age" will mean the even more noxious exploitation of unconventional oil and gas reserves, such as tar sands, extraheavy crudes, and arctic off-shore deposits. ${ }^{42}$ However, in light of a possible decline of fossil energy demand following COVID-19, the petroleum market might in fact not have such a stable future ahead after all. However, despite the fundamental rifts across many different economies, hardly any bailout proposal has so far anchored the reduction of carbon emission and of fossil energy as paramount.

\footnotetext{
${ }^{38}$ See, for instance, Andrew Pendakis, "Being and Oil: Or, How to Run a Pipeline through Heidegger," in Wilson, Carlson, and Szeman, Petrocultures.

39 Sheena Wilson, Imre Szeman, and Adam Carlson, "On Petrocultures: Or, Why We Need to Understand Oil to Understand Everything Else," in Wilson, Carlson, and Szeman, Petrocultures, 4.

${ }^{40}$ Ibid., 5 (italics in the original).

${ }^{41}$ Barrett and Worden, "Oil Culture," 271.

${ }^{42}$ Michael T. Klare, “The Third Carbon Age," Huffington Post, August 8, 2013, updated December 6, 2017, accessed January 27, 2021, https://www.huffingtonpost.com/michael-t-klare/renewable-energy_b_3725777. html.
} 
Iridescence, as analytical concept, acknowledges humankind's complex and highly affective historical relationship with petroleum, in which petroleum is not just hydrocarbons but also plays out as energy, money, power, mobility, speed, destruction, and contamination. It accounts for oil's historical and material legacy of being not one but many different things at once, which has given it a sense of overwhelming and at times magical or haunting potency. Petroleum is the substance that has fueled the highest hopes and the greatest tragedies of modernity as the case study of Kuwait emphasizes.

Petro-modernity is situated in the Anthropocene, the ongoing era of human-induced environmental change, whose "scale of burning ambitions of fossil-making man ... is hard to comprehend." ${ }^{43}$ Petro-modernity is also difficult to investigate in relation to visual culture given "how deeply embedded in our very sensorium and modern ways of seeing the Anthropocene-aesthetic-capitalist complex of modern visuality has become" and how fundamentally it relies on the burning of fossil fuels as Mirzoeff has high-lighted. ${ }^{44}$ Conceptually, the experience of living with oil has been described as "petrofictions" (Imre Szeman), "petromodernity" (Stephanie LeMenager), "oil modernity" (Nelida Fuccaro), "petroleumscape" (Carola Hein), and as "oil culture," which art historian Ross Barrett and literature scholar Daniel Worden define as "the broad field of cultural representation and symbolic forms that have taken shape around the fugacious material of oil." ${ }^{45}$ Historian Bob Johnson speaks about "mineral rites" that highlight the "embodiment of fossil fuels, including our affective attachments to them." ${ }^{46}$ Energy humanist Stephanie LeMenager describes living in petro-modernity as living in a modern world "based in the cheap energy systems made possible by oil." ${ }^{47}$

Building on LeMenager's definition, in this study the term petro-modernity is expanded (1) to also describe the historical period since the mid-nineteenth century, when modern oil production started and the use of petroleum products increased rapidly around the world, the "fossil economy" 48 and (2) to characterize a world in which petroleum and petroleum-derived products (and the set of practices associated

\footnotetext{
${ }^{43}$ For a thought-provoking discussion of the fossil-burning concept of the Anthropocene and alternative proposals for characterizing our time and our relationship to nature, see Donna Haraway, “Tentacular Thinking: Anthropocene, Capitalocene, Chthulucene," e-flux journal, no. 75 (September 2016), accessed January 27, 2021, https://www.e-flux.com/journal/75/67125/tentacular-thinking-anthropocene-capitalocene-chthulucene/.

${ }^{44}$ Mirzoeff, "Visualizing the Anthropocene," 213.

${ }^{45}$ Szeman, "Introduction to Focus," 3; Stephanie LeMenager, Living Oil: Petroleum Culture in the American Century, Oxford Studies in American Literary History (New York: Oxford University Press, 2014), 67; Nelida Fuccaro, "Visions of the City: Urban Studies on the Gulf," Middle East Studies Association Bulletin 35, no. 2 (2001): 179; Carola Hein, "Oil Spaces: The Global Petroleumscape in the Rotterdam/The Hague Area," Journal of Urban History 44, no. 5 (2018): 888; Barrett and Worden, “Oil Culture," 269.

${ }^{46}$ Bob Johnson, Mineral Rites: An Archaeology of the Fossil Economy (Baltimore: Johns Hopkins University Press, 2019), 2.

${ }^{47}$ LeMenager, Living Oil, 67.

48 Johnson, Mineral Rites, 9.
} 
with prospecting for, discovering, controlling, producing, and refining petroleum) have infiltrated ways of living, beliefs, and especially images and aesthetics through which we experience and negotiate the world. Especially because we make sense of the world through cultural representations, text and images provide pivotal access points for the detection and disclosure of petro-modernity.

Developed over the last two or three decades but predominantly within the last ten years, the research on oil within the humanities and social sciences is impressive and has been extremely inspiring. Even mainly socioeconomically oriented anthologies on petroleum include discussions of artworks, and scholars often team up with artists to produce visual essays and academic research. This underscores the importance (and ongoing challenge) of the visual in the field of petroleum studies. ${ }^{49}$ However, systematically tracing the (in)visibilities, imagery, and imaginaries that the world of petroleum produce in relation to a particular visual medium has predominantly been done in relation to film.

Petroleum has in fact proven essential to (the history of) film: not only were early film rolls petroleum-derived products, but, as Mona Damluji has shown, oil companies were important producers of documentary films to promote their extractive operations and to control their public image. ${ }^{50}$ Rising numbers of documentaries attempt to come to terms with the global fossil dependency and its environmental consequences, but, as Imre Szeman argues, they struggle to formulate a clear political agenda in the face of oil. ${ }^{51}$ Films like Werner Herzog's Lessons of Darkness (1992) on the burning of oil fields in Kuwait after the Operation Desert Storm and George Stevens's Giant (1956), which portrays the experience of the oil boom in Texas, have become key filmic dioramas from which to analyze visual representations of the petroleum experience. ${ }^{52}$

Artists like Ursula Biemann have been pivotal contributors to a critical understanding of petroleum through artworks and text. ${ }^{53}$ In Black Sea Files (2005), Biemann investigates

\footnotetext{
${ }^{49}$ For example, the anthology Subterranean Estates includes an article on the photographs of Ed Kashi. On other scholar-artist teams, see Biemann and Pendakis, "This is Not a Pipeline"; Michael Watts and Ed Kashi, "Oil City: Petro-Landscapes and Sustainable Futures," in Ecological Urbanism, ed. Mohsen Mostafavi and Gareth Doherty (Baden: Lars Müller, 2010); Imre Szeman and Maria Whiteman, "Oil Imaginaries: Critical Realism and the Oil Sands," Imaginations: Journal of Cross-Cultural Image Studies 3, no. 2 (2012).

${ }^{50}$ Damluji, "Petroleum's Promise."

${ }^{51}$ Imre Szeman, "Crude Aesthetics: The Politics of Oil Documentaries," Journal of American Studies 46, no. 2 (2012).

${ }^{52}$ Herzog filmed Lessons of Darkness during the oil field burnings in Kuwait immediately after the Iraqi invasion had ended. See Imre Szeman, "The Cultural Politics of Oil: On Lessons of Darkness and Black Sea Files," Polygraph, no. 22 (2010); Daniel Worden, "Fossil-Fuel Futurity: Oil in Giant," Journal of American Studies 46, no. 2 (2012).

${ }^{53}$ Examples include Per Barclay's photographic series Oil Room (1989), which shows oil-flooded interior spaces; Christo and Jeanne-Claude's The London Mastaba (2018), an installation of multi-colored oil barrels stacked on a floating platform in Serpentine Lake, London; and Edward Burtynsky's photography of petroleum landscapes, in Edward Burtynsky and Michael Mitchell, Edward Burtynsky: Oil (Göttingen: Steidl, 2009).
} 
the networks, flows, infrastructures, and social communities that embody oil culture in everyday spaces of the Caspian oil geography. She argues that "the discovery of the vast potential of oil for the creation of new materials mustering an extraordinary range of qualities has fueled our imagination to create a synthetic world and overcome natural limits." ${ }^{54}$ However, many exhibitions and artworks that deal with petroleum tackled the issues of pollution, sustainability, and violence, often under the label of Eco Art, although seldom asking questions how the aesthetics of petroleum and the ways in which it has historically shaped vision and imaginations, are part and parcel of an iridescent, ambivalent petro-modernity. A notable exception is the exhibition Crude (2019), which Murtaza Vali curated at the Jameel Arts Centre in Dubai, and which explores the ways in which contemporary artistic practices negotiate the experience of petro-modernity within the Arab world. ${ }^{55}$ The fact that two large exhibitions on the historical artistic and cultural implications of petroleum are scheduled for 2021-22 indicates the rising interest in petroleum as a visual phenomenon and the exhibition as a medium to investigate and discuss it in a broader public sphere. ${ }^{56}$

Astonishingly, although art historians are intimately familiar with "oil" on canvas, they have not (yet) focused on the petro-experience of the world, as the scarcity of the research output shows. ${ }^{57}$ Notable exceptions are the work of Amanda Boetzkes, who tackles plastics and waste in contemporary art, and of Heather M. Davis, who works on plastic as cultural practice and art material. ${ }^{58}$ These works help reflect on petroleum-derived materials in artistic practice but are mostly limited to plastic. Focusing on a different material aspect, architect Mirko Zardini's poetic and thought-provoking essay "Homage to Asphalt," which unravels the bituminous "second crust of the Earth" as something that signifies urbanity and facilitates speedy movement, is also worth mentioning. ${ }^{59}$ Recently established research projects such as Ecology and Aesthetics: Environmental Approaches in Art History at Kunsthistorisches Institut in Florenz - Max-Planck-Institut

\footnotetext{
${ }^{54}$ Biemann and Pendakis, "This is Not a Pipeline," 9.

${ }_{55}$ Murtaza Vali, Crude (Dubai: Art Jameel, 2019), exhibition catalog published in conjunction with the exhibition of the same name, shown from November 11, 2018, until March 30, 2019.

${ }^{56}$ The exhibition Oil: Schönheit und Schrecken des Erdölzeitalters (Oil: Beauty and Horror in the Petrol Age) is shown at Kunstmuseum Wolfsburg, Germany, starting in September 2021, and is curated by Alexander Klose and Benjamin Steininger together with Andreas Beitin. The exhibition Experiences of Oil will open at Stavanger Kunstmuseum, Norway, in November 2021 and is curated by Anne Szefer Karlsen and Helga Nyman.

57 The oil paint used in oil paintings is actually not a petroleum derivative at all; instead, it consists of color pigments suspended in a drying oil, such as linseed oil. In contrast, acrylic paint, which was invented in the first half of the twentieth century, and which is today often used as a cheaper alternative to oil paint, is made from pigments suspended in an acrylic polymer emulsion, which is a petroleum-based synthesized product. ${ }^{58}$ Amanda Boetzkes, Plastic Capitalism: Contemporary Art and the Drive to Waste (Cambridge, MA: MIT Press, 2019); Heather M. Davis, "Life \& Death in the Anthropocene: A Short History of Plastic." In Art in the Anthropocene: Encounters Among Aesthetics, Politics, Environments and Epistemologies, ed. Heather Davis and Etienne Turpin (London: Open Humanities Pres, 2015).

59 Mirko Zardini, “Homage to Asphalt," Log, no. 15 (2009).
} 
or Mediating the Ecological Imperative at the University of Bern are promising to open up the discipline's canon for environmental and ecological perspectives already established in various humanistic disciplines. ${ }^{60}$

Another important thematic cluster related to the multidisciplinary research on oil is centered around motorized speed and mobility. In the twentieth century, car culture and other forms of motorized mobility like air travel have emerged as crystallization points from which to tackle petroleum. As one research group puts it, "as oil and gas move through our lives, our movement is in turn enabled by them, in cars, planes, asphalt, the plants that make our bicycles, electric cars, and public transportation vehicles." ${ }^{\prime 1}$ Existing studies with a focus on the Arabian Peninsula have, for instance, concentrated on car drifting and youth revolts in Saudi Arabia, on the promotion of driving as a part of US national identity, and on the "nationalization" of space in the UAE through infrastructures such as highways and suburban neighborhoods that demand automobility. ${ }^{62}$

Not only does petroleum enable all sorts of mobility, but it is also itself extremely mobile, frequently crossing language boundaries and national borders on its way from extraction site to refinery and local as well as global consumers. Oil's mobility is also methodologically challenging because it "complicates not only historical periodization but also the national boundaries that conventionally limit scholarly inquiry." ${ }^{3}$ Therefore, the field of petro-culture or petro-modernity studies demands transnational and transdisciplinary research into the experiences with and of petroleum of various geographical areas.

Bridging fossil-fueled movement with petroleum-related infrastructures, Andrew Pendakis remarks that "our conception of oil is usually oriented by this wide-angle image of the silently running oil refinery or platform," through which, he warns, "oil is ... dangerously literalized, wrongly conceived as simply coextensive with a highly simplified figure of its own productive apparatus." ${ }^{64}$ Contrary to this, the fields of "infrastructure studies" or science and technology studies (STS) have undertaken challenging investigations into the material, cultural, social, economic, and political entanglements

\footnotetext{
${ }^{60}$ The research project Ecology and Aesthetics: Environmental Approaches in Art History is directed by Gerhard Wolf und Hannah Bader in collaboration with Sugata Ray, accessed January 27, 2021, https://www. khi.fi.it/en/forschung/abteilung-wolf/ecology-and-aesthetics-environmental-approaches-in-art-history.php. Mediating the Ecological Imperative is a multidisciplinary project including art history that is funded by the Swiss National Science Foundation for the period 2021-24, accessed January 27, 2021, https://ecological-imperative.ch/.

${ }^{61}$ Appel, Mason, and Watts, “Oil Talk," 27.

62 Pascal Menoret, Joyriding in Riyadh: Oil, Urbanism, and Road Revolt (New York: Cambridge University Press, 2014); Sarah Frohardt-Lane, "Promoting a Culture of Driving: Rationing, Car Sharing, and Propaganda in World War II," Journal of American Studies 46, no. 2 (2012), special issue: Oil Cultures; Matthew MacLean, "Suburbanization, National Space and Place, and the Geography of Heritage in the UAE," Journal of Arabian Studies 7, no. 2 (2017).

${ }^{63}$ Barrett and Worden, "Oil Culture," 271.

${ }^{64}$ Biemann and Pendakis, "This Is Not a Pipeline," 8.
} 
of infrastructures, focusing on roads, dams, and other structures. ${ }^{65}$ The infrastructure of the oil industry itself-the oil towers, pipelines, oil tanks, oil tankers, refineries, petrol stations, and so on-is nevertheless crucial to simultaneously highlight petroleum and hide it in plain sight, disguising its mobility, transformation, and impact. ${ }^{66}$ For example, the authors of the anthology Subterranean Estates have called for an acknowledgment of the site-specificity of the oil industry despite its apparent global normalization and standardization. ${ }^{67}$ Architect and cultural theorist Rania Ghosn has unraveled the pipeline as a key spatial site in the maintenance of oil, and Carola Hein has attempted to establish a spatial typology that highlights the entanglements between oil well and oil company office with the concept of the "petroleumscape." 68

Urban space has been petroleum's favorite stage and preferred playground. Many studies investigate the spatial, urban, and architectural implications of petroleum, and some of these focus on the Gulf. Social historian and Gulf specialist Nelida Fuccaro has been a particularly thought-provoking voice; her work comprises studies that examine the complex sociopolitical historical relationships between the "pearl towns" and "early oil cities" and explores the ways in which "cities and urban environments [have] constituted the primary setting where oil modernity unfolded." ${ }^{69}$ Fuccaro's approach has helped shape the present study's conceptualization of the oil-fueled urban transformation of Kuwait City.

\subsection{Modernization and Urban Transformation}

The analysis of urban images in relation to Kuwait City in the mid-twentieth century implies focusing not only on modes of pictorial depiction but also on the image, the reputation, and the external and self-representation of oil states. This is because understanding the common ways of framing the Gulf region and other oil-producing

\footnotetext{
${ }_{65}$ Penelope Harvey and Hannah Knox, eds., Roads: An Anthropology of Infrastructure and Expertise (Ithaca: Cornell University Press, 2015); Maria Kaika, "Dams as Symbols of Modernization: The Urbanization of Nature between Geographical Imagination and Materiality," Annals of the Association of American Geographers 96, no. 2 (2006).

${ }^{66}$ On this point in relation to refineries, see Steininger, "Refinery and Catalysis," 111.

${ }^{67}$ Appel, Mason, and Watts, "Oil Talk," 18.

${ }^{68}$ Rania Ghosn, “Territories of Oil: The Trans-Arabian Pipeline," in The Arab City: Architecture and Representation, ed. Amale Andraos, Nora Akawi, and Caitlin Blanchfield (New York: Columbia Books on Architecture and the City, 2016); Hein, "Oil Spaces."

${ }^{69}$ Nelida Fuccaro, "Pearl Towns and Early Oil Cities: Migration and Integration in the Arab Coast of the Persian Gulf," in The City in the Ottoman Empire: Migration and the Making of Urban Modernity, ed. Ulrike Freitag et al., SOAS/Routledge Studies on the Middle East 14 (London: Routledge, 2011); Nelida Fuccaro, "Introduction: Histories of Oil and Modernity in the Middle East," Comparative Studies of South Asia, Africa and the Middle East 33, no. 1 (2013): 1; and also Fuccaro, "Visions of the City."
} 
countries at the time-from the outside as well as from the inside-are crucial for the historical contextualization of the visual materials.

These extended 1950s, the period between Kuwait's first oil export in 1946 and its independence from Britain in 1961, coincided with the heyday of Anglo-American modernization and development theory, which influenced the way in which Kuwait's petro-modernity was (inter)nationally interpreted and (visually) represented. These theories were built on grand historical-comparative concepts and strategies of macrosocial change that attempted to provide historical explanations of why some nations were more advanced than others and to deliver schemes of how to develop the world, especially targeting so-called developing countries like Kuwait. ${ }^{70}$ It is no surprise that fossil energies played a role already in projecting progress in this context.

Kuwait was neither an empirical nor a political focus of Anglo-American modernization efforts, as seminal publications on modernization in the Middle East did not include Kuwait in any significant way. ${ }^{71}$ Yet, as a British quasi-protectorate since 1899 and neighbor of Saudi Arabia, America's prime petroleum partner, Kuwait was situated within a regional sphere of declining British power and rising US influence. This also infused Kuwait and its external but also internal image with the prevailing modernization and development ideologies of the time. ${ }^{72}$

Broadly speaking, modernization theory describes society's accelerated, linear, and unilateral development path from a traditional, agrarian, and rural stage to a modern, industrial, urban, and democratic one through the injection of Western technological, economic, and political assistance; this process was famously called "take-off" by modernization theorist Walt Whitman Rostow. ${ }^{73}$ Economic growth and industrialization were hailed as prime instruments to stimulate transformation processes toward a Western (West European and Anglo-American) modernity characterized by free-market capitalism, liberal democracy, institutional differentiation, urbanization, rationalization, welfare, mass consumption, and so on. ${ }^{74}$ Sociologist Wolfgang Knöbl has asserted that the inherent ethnocentrism is highly problematic, insofar as "the sociopolitical structure

\footnotetext{
${ }^{70}$ However, Knöbl cautions that US sociologists, who laid the founding stones for theories of modernization, did not in fact analyze the historical development of American society in order to project a path model, but instead developed historical explanation models of how other (underdeveloped) countries should develop by empirically researching their "still traditional” status quo. Wolfgang Knöbl, Spielräume der Modernisierung: Das Ende der Eindeutigkeit (Weilerswist: Velbrück Wissenschaft, 2001), 34.

${ }^{71}$ Daniel Lerner, The Passing of Traditional Society: Modernizing the Middle East (New York: Free Press, 1958); Manfred Halpern, The Politics of Social Change in the Middle East and North Africa (Princeton: Princeton University Press, 1963).

${ }^{72}$ See Simon C. Smith, "Power Transferred? Britain, the United States, and the Gulf, 1956-1971," Contemporary British History 21, no. 1 (2007).

${ }^{73}$ Walt Whitman Rostow, The Stages of Economic Growth: A Non-Communist Manifesto (Cambridge, UK: Cambridge University Press, 1960), chapter 4.

${ }^{74}$ Doubts over a directly quantifiable interdependency between economic-industrial change and democratization were formulated early on; see Knöbl, Spielräume der Modernisierung, 190-96.
} 
of the West represented a kind of end point" that non-Western states were pressured to follow. ${ }^{75}$ Moreover, modernization implied catching-up with something already achieved by others instead of inventing new and original future scenarios tailored to site-specific conditions on the ground. Modernization often meant nothing else than working with or toward the current standards set by others by means of foreign aid.

A certain geo-political or economic relevance to Anglo-American interests was needed for a country to become a target of foreign modernization efforts. Kuwait entered the modernization picture only when oil was struck. Petroleum extraction and export started in 1946 and by 1951 a new 50/50 profit-sharing oil deal between the Kuwaiti government and the Kuwait Oil Company had been agreed upon. Suddenly, the country's oil revenues provided the capital needed to both stimulate and finance the city-state's modernization. Ironically, it was Kuwait's sudden affluence and not its previous (relative) poverty that triggered the strong increase of British, and generally foreign, interest in modernizing Kuwait. $^{76}$

Britain intended to control Kuwait's oil-fueled development to shore up its own financial and political interests. A development board with two British advisors as controller of finances and controller of development was established in 1950 and was expected to effectively monitor and channel the spending of surplus oil revenues according to British interests. ${ }^{77}$ Another typical strategy was the (temporary) posting of mostly British advisors and experts, among them architects and urban planners, to advise and simultaneously steer Kuwait's development. However, in the 1950s, Britain's power in the Middle East and the Persian Gulf was rapidly declining. Additionally, Britain suffered so greatly from the weak sterling area that it in effect froze Kuwaiti surplus oil revenues in London in order to secure stabilization. Therefore, a strong discrepancy between British development aid rhetoric and the partial blocking of capital needed to initiate largescale projects existed at the time. ${ }^{78}$ Terms like "modernization" and "development" often functioned as a political disguise for British interests in the Gulf; development consisted mainly of advising and ensuring commissions of British firms, thus securing additional shares of oil revenues, instead of providing British state-funded development investments or initiatives tailored predominantly to Kuwaiti needs. ${ }^{79}$

\footnotetext{
75 Ibid., 11 (author's translation).

${ }^{76}$ Simon C. Smith, “A Vulnerable Point in the Sterling Area': Kuwait in the 1950s," Contemporary British History 17, no. 4 (2003): 37, https://doi.org/10.1080/13619460308565456.

77 See Al-Nakib, Kuwait Transformed, 105-7.

${ }^{78}$ Paul W. T. Kingston, Britain and the Politics of Modernization in the Middle East: 1945-1958, Cambridge Middle East Studies 4 (Cambridge, UK: Cambridge University Press, 1996), 42-45.

${ }^{79}$ Ali Karimi and Frederick Kim, "On Protectorates and Consultanates: The Birth and Demise of Modernization in the Gulf States," in Unsettling Colonial Modernity in Islamicate Contexts, ed. Siavash Saffari et al. (Newcastle-upon-Tyne: Cambridge Scholars, 2017), 96; J. E. Peterson, "Britain and the Gulf: At the Periphery of Empire," in Potter, The Persian Gulf in History, 284; Rosemarie Said Zahlan, The Making of the Modern Gulf States: Kuwait, Bahrain, Qatar, the United Arab Emirates and Oman (London: Unwin Hyman, 1989), 33.
} 
Petroleum also played a crucial role in the theoretical conceptualization of modernization. Apart from the importance of oil revenues as capital to stimulate economic growth and industrialization, petroleum was acknowledged as being relevant to motorized mobility, electrification, and urbanization-basically to pivotal markers of being modern. For example, American sociologist Marion J. Levy characterized modern societies not only by industrialization and rationalization, but also by their high consumption of energy and the use of non-animated matter (like coal and petroleum) for power generation. ${ }^{80}$ One of the most prominent scholars of modernization, the American economist and political theorist Walt Whitman Rostow, proposed that the automobile was the key to becoming modern or to reaching what he called the "age of high mass consumption." ${ }^{81}$ As early as the 1950s, modernization had already become clearly unthinkable without fossil energy and thus petroleum, independently of the question of whether a country was an oil producer or not. In this logic, development was tied to the accessibility of fossil energy, petroleum-derived materials and consumer goods, and (petro)capital.

The modernization of the city-state Kuwait was measured especially by its level of oilstimulated urban growth, which increased considerably from the late 1940s onward. This urban transformation involved a complex shift in labor migration (attracted by the growing economy) and higher birth rates, which, along with other factors, accounted for the explosive growth of Kuwait City. The transformation also included a radical change of the city's layout, form, and silhouette. The economy transitioned from seafaring, shipbuilding, and trading to a welfare system that relied almost exclusively on oil revenues distributed by the rulership. The vernacular architectural style gave way to idioms typical of the International Style and manifested in industrial building materials. Professions, ways of living and socializing, education trajectories, and social cohesion all changed. These are just a few of the aspects associated with Kuwait's complex urban transformation. ${ }^{82}$

It was only in the 1980s that the relationship between oil (booms) and urbanization was systematically analyzed on a macro level for the first time. One important triggering event for this was the startling 1973 "oil crisis," which unfolded in the form of skyrocketing oil prices in the West and resulted in soaring revenues and building booms in the oil-producing OPEC countries. Subsequently, economists, political scientists, and geographers examined the spatial and socioeconomic characteristics of the sudden impact of oil on urban space, which was predominantly observed within the rapidly transforming

\footnotetext{
${ }^{80}$ Marion J. Levy, Jr., "Some Sources of the Vulnerability of the Structures of Relatively Non-Industrialized Societies to Those of Highly Industrialized Societies," in The Progress of Underdeveloped Areas, ed. Bert F. Hoselitz (Chicago: University of Chicago Press, 1952), 115. Levy's take on modernization is analyzed in Knöbl, Spielräume der Modernisierung, 160-73.

${ }^{81}$ See Nils Gilman, Mandarins of the Future: Modernization Theory in Cold War America, New Studies in American Intellectual and Cultural History (Baltimore: Johns Hopkins University Press, 2003), 190-202.

${ }^{82}$ Urban transformation entails always more than just urban growth. Still, at the time, (Kuwait's) urban transformation was often subjected to such limited definition. See Josef Gugler, ed., The Urban Transformation of the Developing World (Oxford: Oxford University Press, 1996).
} 
OPEC member states, including Kuwait and other Gulf states. ${ }^{83}$ Coined "petro-urbanism" or "oil urbanization," such transformation was generally characterized as an extremely rapid, large-scale, and in this form unprecedented acceleration of urbanization that resulted from the surge in oil revenues and the subsequent economic boom in the small oil-producing states of the Gulf of the 1970s. ${ }^{84}$ Other important factors were the shift in demographics toward an extremely heterogeneous, non-citizen majority and the strengthening of existing urban centers. Geographers Michael E. Bonine and Rainer Cordes also emphasized the adaptation of urban space to motorization, the energyintensive climate-controlling of architecture, and the influence of Western consultants on building and planning. ${ }^{85}$ To this day, as Laure Assaf and Clémence Montagne have recently observed, "The urban phenomenon"-and one should add the petroleum-fueled urban phenomenon - "has been the main lens through which the idea of an exceptionality of the Arab Gulf states was elaborated in academic scholarship." 86

Although scholars agree that the 1970s marked the core phase of "petro-urbanism," they differ on when exactly to place the starting point of the petroleum-induced change in urbanization patterns in the Gulf. That this starting point was considered a watershed moment is shown in the temporal categories of "pre-oil" and "post-oil" that became firmly established in the 1980s. In the assessment of Mohamed Riad, an Egyptian geographer, the understanding of time and history in this regard had already been affected by oil in 1981:

One should be aware that the term "past," in the Gulf area does not necessarily refer to any appreciable time distance. It simply refers to pre-oil periods which ended around the fifties of this century. Since it is so near, it is vivid and nostalgic in the lore of the people, but to the new generation it is antiquated. ${ }^{87}$

\footnotetext{
${ }^{83}$ The Organization of the Petroleum Exporting Countries (OPEC) was established in 1960 in Baghdad by the founding members Iran, Iraq, Kuwait, Saudi Arabia, and Venezuela. OPEC's goal is to regulate oil market prices and represent the economic and political interests of these national oil producers. By 1973, Algeria, Ecuador, Indonesia, Libya, Nigeria, Qatar, and the United Arab Emirates had also joined.

${ }^{84}$ See, for example, Mohamed Riad, "Some Aspects of Petro-Urbanism in the Arab Gulf States," Bulletin of the Faculty of Humanities and Social Sciences, no. 4 (1981): 17; Michael E. Bonine and Rainer Cordes, "Oil Urbanization: Zum Entwicklungsprozess eines neuen Typs orientalischer Städte," Geographische Rundschau 35, no. 9 (1983): 465.

${ }^{85}$ See Riad, "Some Aspects of Petro-Urbanism in the Arab Gulf States"; Bonine and Cordes, "Oil Urbanization," here 465; Salih A. El-Arifi, "The Nature of Urbanization in the Gulf Countries," GeoJournal 13, no. 3 (1986); Sulayman Khalaf and Hassan Hammoud, "The Emergence of the Oil Welfare State: The Case of Kuwait," Dialectical Anthropology 12, no. 3 (1987); Richard I. Lawless and Ian J. Seccombe, "Impact of the Oil Industry on Urbanization in the Persian Gulf Region," in Urban Development in the Muslim World, ed. Hooshang Amirahmadi and Salah S. El-Shakhs (New Brunswick: Rutgers University Press, 1993).

${ }^{86}$ Assaf and Montagne, "Urban Images and Imaginaries," 6.

${ }^{87}$ Riad, "Some Aspects of Petro-Urbanism in the Arab Gulf States," 10.
} 
Depending on each oil-producing country's specific experience with oil, authors tend to draw the line of the pre-oil period around the 1950 s or the $1960 \mathrm{~s} .{ }^{88}$ For the case of Kuwait, the end of the pre-oil period can be determined with the first export of oil in 1946. While pre- and post-oil seem to be useful categories, the latter causes confusion because it is sometimes used to refer to a time "after" the discovery of oil and sometimes to a time in the future when oil is no longer (as) necessary. To provide a clear differentiation when speaking about Kuwait's history, in the present study the terms "pre-oil" and "oil" are used to describe the periods before 1946 and after 1946 respectively, while the term "after oil" is used to refer to a future in which oil will not be the dominant energy and material base of our world. The dominant characteristics of oil urbanization might have manifested most intensely during the 1970s, but the case of Kuwait City clearly shows that from the late 1940s onward (and especially during the 1950s) all of the above-mentioned factors of petro-urbanism already impacted the city majorly.

Descriptions of "petro-urbanism" or "oil urbanization," have established a narrative of Kuwait's urban transformation as a radical break from the past. In line with the logic of modernization theory, the notion of urban transformation often implies firm binaries of the old and traditional versus the new and modern in urban form and social structure. This is also the case when developments in Kuwait are described along the lines of without oil vs. with oil. Instead of thinking of the pre-oil and the oil periods as totally separated eras, however, the concept of "transformation" put forward by German social and political scientist Rolf Reißig stimulates a more refined understanding.

Reißig defines transformation as a "change that always includes continuity as well." 89 He describes it further as "an intentional, intervening, organizing, and at the same time self-stimulated, organic-revolutionary process of development. Historical processes that take on the character of transformation are as a rule driven by both processes [change and continuity]." ${ }^{90}$ Consequently, Kuwait City's urban transformation is not analyzed according to existing macro-level typologies or concepts of oil-induced modernization and urbanization. Instead, the architectural and spatial outcomes and visual expressions and representations of this complex, ambiguous, and impactful process are understood as containing both change and continuity. This approach also considers that oil cities are no longer analyzed merely as the spatial products of petro-urbanization but rather, on the

${ }^{88}$ In favor of the 1950s see ibid., 17; El-Arifi, “The Nature of Urbanization in the Gulf Countries", 224. In favor of the 1960s see Nelida Fuccaro, “Visions of the City: Urban Studies on the Gulf”, Middle East Studies Association Bulletin 35, no. 2 (2001): 176-77. Khalaf situates the end of the pre-oil period for Kuwait, Bahrain, and Qatar in the 1950s and for the UAE and Oman in the 1960s; see Sulayman Khalaf, "The Evolution of the Gulf City: Type, Oil, and Globalization," in Globalization and the Gulf, ed. John W. Fox, Nada MourtadaSabbah, and Mohammed A. Mutawa (London: Routledge, 2006), 248.

${ }^{89}$ Rolf Reißig, “Transformation - ein spezifischer Typ sozialen Wandels: Ein analytischer und sozialtheoretischer Entwurf," in Futuring: Perspektiven der Transformation im Kapitalismus über ihn hinaus, ed. Michael Brie (Münster: Westfälisches Dampfboot, 2014), 54 (author's translation).

90 Ibid. 
micro-level, as multi-sensory environments or stages of the urban visual culture of petromodernity as this book does. For instance, Michael Watts and Ed Kashi's definition of the "oil city" implies that "much of what is modern in the modern city is the by-product of oil. The city as a way of life is, in this specific sense, petro-urbanism a la lettre." ${ }^{91}$ Moreover, Kuwaiti architectural historian Asseel Al-Ragam has emphasized that Kuwait City's development "was intimately connected with its determination to reuse existing sites for modern functions." ${ }^{2}$ This can be seen in the fact that the modern oil city was conceived both visually and physically on top of the existing coastal settlement, a development that is emblematic of urban transformation as a process of change and continuity.

As Kuwait City was physically altered it was simultaneously created in visual representations which in turn shaped the further course of urban planning and rebuilding and constructed how the city was perceived while it was continuously changing. Still, many authors argue that image creation and "city branding" is something that only comes after the basic infrastructure of a city and a certain level of "modernization" has been established. For example, a 2017 article on Dubai discussing the "Birth and Demise of Modernization in the Gulf States" states:

Whereas thirty years prior, the main concerns were the provision of water, electricity, and healthcare, the preoccupation now [around 1979] became how to purchase an identity and create a brand for the city that would make it known throughout the world. This is not to be understood as a breaking away from the trajectory of modernization, but in fact its apotheosis. Once the basic provisions of civilization had been fulfilled, the project of modernization became one of capitalist consumption driven by the pace that had been set years prior, but also one of self-reflection and the need to prove to the world that the developing countries had modernized. ${ }^{93}$

In contrast, the example of the urban transformation of Kuwait City during the extended 1950s shows that the forging of visual representations of modern architecture, urban space, and infrastructures served as effective proof of the city-state's modernization while it was still ongoing. Furthermore, it indicates that such imagery was therefore an intrinsic part of the fast-paced modernization in the Gulf region and continues to be as Laure Assaf and Clémence Montagne have demonstrated.${ }^{94}$ Moreover, many projected development projects were even foreshadowed by images and at times have remained as images only. These visual representations were influential in the way that they created the image of the city according to different agendas; a quasi-forerunner of the prevalence of city branding in relation to the Gulf cities today. ${ }^{95}$

${ }^{91}$ Watts and Kashi, "Oil City", 93 (italics in the original).

${ }_{92}$ Asseel Al-Ragam, "Towards a Critique of an Architectural Nahdha: A Kuwaiti Example," (PhD diss., School of Architecture, University of Pennsylvania, 2008), accessed September 29, 2019, https://repository. upenn.edu/dissertations/AAI3309387/, 34.

${ }_{93}$ Karimi and Kim, "On Protectorates and Consultanates," 97.

${ }^{94}$ Laure Assaf and Clémence Montagne, "Urban Images and Imaginaries: Gulf Cities through Their Representations," Arabian Humanities, no. 11 (2019).

${ }^{95}$ Ibid., 1. 
In Kuwait, just like in other oil-producing countries, the interest in visual representation was also triggered by the competitive, comparative, and international nature of the oil industry. Projecting "correct" development was obviously a valuable currency of an oil state's self-representation to the outside that facilitated good relations with other states, prominence, and simply presence. (Portable) visual artifacts affected and facilitated the nation-building process and allowed for transnational and transcultural communication, in many ways flowing through the same networks that the oil companies and petro-modernity had opened up. ${ }^{96}$ The Kuwait Oil Company actively partook in the project to visualize and thereby curate Kuwait City. Even more marginal agents, ordinary people, living in Kuwait engaged visually and aesthetically to various ends; visual artists established shared practices, networks, and spaces for the visual arts; homeowners engaged in architectural explorations by commissioning spectacular designs; Arab and Kuwaiti writers forged new, often illustrated magazines and the city became itself a popular display for posters, illuminated advertising, shop windows, and billboards_increasingly experienced while driving a car. Yet, the new petro-fueled imagery needs to be read against the pre-oil background of the coastal town, its pre-oil visual and material culture and urban history, too. Only in this way can justice be paid to understanding the complexities of Kuwait's urban transformation as a "change that always includes continuity as well."

\footnotetext{
${ }^{96}$ Similarly, Mona Damluji has based her analysis of oil company films on the understanding "that the context of nation building was being actively produced through the content of oil company films." Damluji, "Petroleum's Promise," 9.
} 
